УДК 623.765:681.513.6

${ }^{1}$ Михайло Іванович Литвиненко (канд. техн. наук, доцент)

${ }^{2}$ Володимир Сергійович Мажнаров

${ }^{3}$ Сергій Ігорович Антоненко

${ }^{1}$ Харківський національний університет Повітряних Сил ім. І. Кожседуба, Харків, Украӥна

${ }^{2}$ Кіровоградська льотна академія Національного авіаційного університету, Кропивницький, Украӥна

${ }^{3}$ Національний університет оборони Украӥни імені Івана Черняховського, Київ, Украӥна

\title{
МОДЕЛЬ ВНУТРІШНЬОЇ МОВИ СИСТЕМИ ПІДТРИМКИ ПРИЙНЯТТЯ РІШЕНЬ АВТОМАТИЗОВАНОЇ СИСТЕМИ УПРАВЛІННЯ ПОВІТРЯНИМ РУХОМ
}

У статті запропоновано модель обмеженої внутрішньої мови системи підтримки прийняття рішень, що є необхідною складовою для реалізаиї прочесу взаємодї̈ між інтелектуальною системою та операторами автоматизованої системи управління повітряним рухом. Розроблена модель є необхідним та обов'язковим засобом формалізації процесів управління повітряним рухом у межах функиіонування системи підтримки прийняття рішень, щчо підвищить рівень автоматизації процесів формування текстових повідомлень у ланках “диспетчер - диспетчер” та “диспетчер - повітряне судно”. За методологією побудови формальної граматики запропоновано структуру словників термінальних та нетермінальних ознак, досить детально описано об'єкти категорій предметної галузі, розроблено редукиійні правила формальної граматики. Коректність отриманого апарату $i$ можливість подальшого практичного використання внутрішньої мови системи підтверджено наведеними прикладами подання знань запропонованою мовою $i$ граматичним розбором конструкцій формул об'єктів.

Ключові слова: інформаційна модель, формальна граматика, термінальні та нетермінальні символи, семантичні ознаки, продукиійні правила.

\section{Вступ}

Інформаційне забезпечення процесів прийняття рішень операторами в автоматизованих системах управління повітряним рухом (АС УПР) має забезпечувати ефективне вирішення функціональних завдань, що вирізняються високою динамічністю зміни умов обстановки, мають нечіткі просторові та часові характеристики.

Постановка проблеми. Аналіз сучасного стану системи інформаційного забезпечення діяльності операторів систем управління повітряним рухом вказує на недостатню опрацьованість питань щодо усунення протиріч до вимог стосовно повноти інформаційних моделей (IM) та оперативності прийняття управлінських рішень, а також можливостей наявних методів і засобів із їх досягнення [1-3].

Насамперед потребують опрацювання питання розроблення й удосконалення системи підтримки прийняття рішень (СППР) операторами АС УПР, а саме розроблення моделей комунікацій на основі обмеженої природної мови операторів із синтезом внутрішньої мови взаємодії системи. Цей аспект спрямований на формалізацію процесу організації діалогового режиму в ланці людина-оператор обчислювальна машина i дає змогу підвищити повноту IM та оперативність прийняття управлінських рішень.

У практичному аспекті недоцільно розглядати використання мов взаємодії СППР і оператора АС УПР 3 точки зору можливості поєднання аморфних та природних мов із пріоритетним урахуванням їх окремих переваг. Доцільнішою $є$ побудова моделі внутрішньої мови взаємодії системи з точки зору можливостей аналізу вхідних повідомлень природною мовою, а саме визначуваних понять, сутностей, відношень, причинно-наслідкових зв'язків тощо [4-12].

Аналіз останніх досліджень і публікацій. Аналіз існуючих моделей мов взаємодії свідчить, що всі моделі мов базуються на багаторівневому описі у вигляді морфологічного, синтаксичного, семантичного та прагматичного описів. Щоб отримати відповідну структуру мови взаємодії, в різних моделях мов використовуються різноманітні лінгвістичні та екстралінгвістичні засоби, вибір яких залежить від специфіки предметної галузі, де необхідно забезпечити потрібну якість вирішення функціональних завдань [1, 5-18].

Таким чином, 3 точки зору специфіки завдань, вирішуваних СППР, для побудови моделі внутрішньої мови взаємодії інтелектуальної системи найдоцільнішим $є$ використання апарату формальних граматик 3 можливим розширеним їх поданням за допомогою побудови правил, що враховують семантичні особливості подання предметної галузі.

Відомі методи і методики формування й управління IM, що складаються в повітряному просторі, не враховують проблематики формування повідомлень в АС УПР обмеженою природною мовою взаємодії та не передбачають формалізації цього процесу 3 розробленням внутрішньомашинної мови системи, що спирається на внутрішню структуру бази знань i бази даних предметної галузі та враховує лінгвістичні, синтаксичні і семантичні особливості побудови мовних моделей.

Метою цієї статті $\epsilon$ обгрунтування моделі внутрішньої мови взаємодії у системі підтримки 
прийняття рішень операторами АС УПР, яка враховуватиме специфіку функціональних задач 3 управління повітряним рухом шляхом застосування лінгвістичних, синтаксичних та семантичних особливостей побудови мовних об'єктів предметної галузі. Отриманий апарат формалізації комунікацій людина-оператор EOM у підсумку дасть змогу реалізувати взаємодію внутрішньої мови системи з обмеженою природною мовою користувачів.

\section{Виклад основного матеріалу дослідження}

Розроблення моделі внутрішньої мови системи підтримки прийняття рішень

Важливим завданням, що потребує вирішення, $\epsilon$ необхідність реалізації комунікативної взаємодії людини-оператора та ЕОМ, для чого слід розробити апарат формалізації для подання об'єктів предметної галузі 3 урахуванням лінгвістичних, синтаксичних та семантичних особливостей мовних моделей.

Для подання в ЕОМ виразів зчислення необхідно використати формальну модель внутрішньої мови системи. Як модель мови може бути запропонована система такого виду [6- 5, 17-20]:

$$
\mathrm{MM}\langle\mathrm{C}, \mathrm{P}, \mathrm{A}\rangle,
$$

де $\mathrm{C}$ - множина базових елементів мови (словник); $\mathrm{P}-$ множина правил для побудови синтаксично правильних конструкцій мови; А множина конструкцій, які $€$ апріорно правильними.

Розроблення структури словника. На основі положення про те, що основними одиницями мови, необхідними для побудови складніших конструкцій, $€$ словоформи професійної мови користувачів, кожен елемент множини С може бути наведено таким чином:

$$
\mathrm{S}_{\mathrm{i}}\left(\mathrm{ts}_{\mathrm{i}}, \sin \mathrm{t}_{\mathrm{i}}, \operatorname{sem}_{\mathrm{i}}\right)
$$

де $\mathrm{S}_{\mathrm{i}}-i$-та словоформа словника $\mathrm{C}$; $\mathrm{ts}_{\mathrm{i}}-$ тип словоформи, який дає змогу вважати $\mathrm{S}_{\mathrm{i}}$ термінальними $\mathrm{T}$ або нетермінальними $\mathrm{N}$ символами словника; $\sin \mathrm{t}_{\mathrm{i}}-$ синтаксична інформація, що характеризує словоформу $\mathrm{S}_{\mathrm{i}}$; sem $_{\mathrm{i}}$ - сукупність семантичної інформації, яка може бути приписана словоформі $\mathrm{S}_{\mathrm{i}}$ (ознака, характеристика, клас тощо) залежно від класифікації об'єктів предметної галузі.

В підсумку словник поділений на дві множини, що не перетинаються: $\mathrm{V}_{\mathrm{n}}$ та $\mathrm{V}_{\mathrm{t}}$, тобто у формальному поданні $\mathrm{V}_{\mathrm{n}} \cap \mathrm{V}_{\mathrm{t}}=0$, а $\mathrm{C}=\mathrm{V}_{\mathrm{n}} \cup \mathrm{V}_{\mathrm{t}}$.

Відповідно до положень теорії формальних граматик iз символів словника $\mathrm{C}$ будують ланцюги типу $\mathrm{S}_{1} \mathrm{~S}_{2} \mathrm{~S}_{3} \ldots \mathrm{S}_{\mathrm{n}}$, які вважають орієнтованими зліва направо. Якщо ланцюг порожній, тобто не має жодного символу, його позначають як $\mathrm{C}^{\circ}=\Lambda$. Множину всіх можливих ланцюгів (замкнення словника С) може бути визначено згідно з виразом:

$$
\mathrm{C}^{*}=\bigcup_{\mathrm{n}=0}^{\infty} \mathrm{C}^{\mathrm{n}}
$$

Множину непорожніх ланцюгів визначають таким чином:

$$
\mathrm{C}^{+}=\mathrm{C}^{*} \backslash\{\Lambda\}=\bigcup_{\mathrm{n}=1}^{\infty} \mathrm{C}^{\mathrm{n}}
$$

Основною операцією, застосованою до рядків, $\epsilon$ конкатенація ๑, яка формально може бути визначена у вигляді бінарної операції на множині $\mathrm{C}^{*}$ таким чином: $(\alpha, \beta) \rightarrow \alpha \beta$, де $\alpha$ і $\beta$ - довільні ланцюги. По відношенню до операції конкатенації множина $\mathrm{C}^{*} \epsilon$ моноїдом, а $\mathrm{C}^{+}-$напівгрупою. Будь-яка множина ланцюгів $\mathrm{L} \in \mathrm{C}^{*} \in$ формальною мовою i може бути описана за допомогою формальних граматик (ФГ) виду G(L), основи яких були визначені Хомським [17]. Відповідно до наведених міркувань ФГ для опису усіх структур об'єктів може бути задано у такому вигляді:

$$
\mathrm{G}(\mathrm{L})=\left(\mathrm{V}_{\mathrm{T}}, \mathrm{V}_{\mathrm{N}}, \mathrm{P}, \mathrm{A}\right) .
$$

У теорії методів дослідження ланцюгів передбачені дві альтернативні стратегії граматичного розбору: низхідна та висхідна [20].

Для усунення недоліків граматик Хомського, які не враховують семантики, що зрештою ускладнює вихід зі складних ситуацій у процесі розбору вихідного повідомлення, запропоновано враховувати семантичні ознаки через використання семантичних продукційних правил (СПП) такого вигляду:

$$
\mathrm{S}_{\mathrm{k}}\left(\operatorname{sem}_{\mathrm{k}}\right), \mathrm{P}_{\mathrm{z}} \rightarrow \mathrm{S}_{\mathrm{j}}\left(\operatorname{sem}_{\mathrm{j}}\right), \mathrm{P}_{\mathrm{m}} .
$$

Наведене СПП означає: якщо $\mathrm{S}_{\mathrm{k}}$ з відповідною семантичною ознакою наявне у правилі переписування 3 номером $\mathrm{Z}$, то у правилі 3 номером $\mathrm{m}$ має бути словоформа 3 семантичною ознакою $\mathrm{sem}_{\mathrm{j}}$. Завдяки запропонованому розширенню граматик Хомського можна перевіряти на семантичну коректність ланцюги внутрішньої мови системи.

Щоб вибрати альтернативу, СПП (2) слід інтерпретувати таким чином. Якщо $\mathrm{S}_{\mathrm{k}}, 3$ відповідною семантичною ознакою, наявне у правилі переписування 3 номером $\mathrm{z}$, то під час розбору вхідного ланцюга мови вибирають правило 3 номером $\mathrm{m}$ i ті $\mathrm{S}_{\mathrm{j}}$, які мають семантичну ознаку $\mathrm{sem}_{j}$.

Враховуючи розширення до граматики (1), запропонована формальна граматика 3 використанням СПП буде мати такий вигляд:

$$
\mathrm{G}(\mathrm{L})=\left(\mathrm{V}_{\mathrm{T}}, \mathrm{V}_{\mathrm{N}}, \mathrm{P}, \mathrm{SP}, \mathrm{A}\right),
$$

де $\mathrm{SP}$ - семантичні правила.

Для деталізованого опису елементів у складі запропонованої граматики, наступним етапом роботи слід визначити створення словника нетермінальних символів. Для класу задач, які розглянуто у статті, запропоновано такий словник $\mathrm{V}_{\mathrm{N}}$ :

$\mathrm{V}_{\mathrm{N}}=$ \{формула зчислення $(\underline{\Phi})$, опис теорії об'єкта (ТОб), опис структури теорії (СтT), тип об'єкта (을 $)$, ім'я теорії об'єкта (ITO), код області

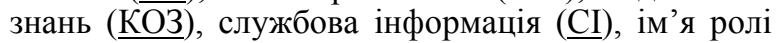

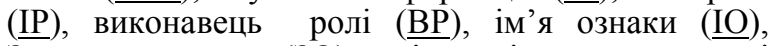
Значення ознаки (3О), зміна оцінки присутності

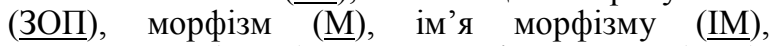
процедури (Проц), кванторні слова (튼),

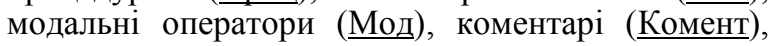


оцінка присутності (ОцПр), розділювачі (*), рядок, слово, цифра, літера, знак, характеристика часу (ХарЧ), міра часу (МЧ), характеристика простору (ХарПрс), міра простору(МПрс), міра якості (Яㅡ), конст1, конст2 \}

Нетермінальний словник зазвичай змістовніший, тому що визначає найбільш загальні синтаксичні елементи виразів зчислення.

Створення вичерпного словника термінальних символів належить до класу завдань, які не мають кінцевого вирішення, тому для практичного застосування під час створення термінального словника достатньо визначити базовий набір елементів.

Пропонується такий базовий словник термінальних символів $\mathrm{V}_{\mathrm{T}}$ в інтересах вирішення завдань оператора АС УПР:

$\mathrm{V}_{\mathrm{T}}=$ \{об'єкт-клас, об'єкт простору, об'єкт часу, об'єкт-дія, об'єкт-стан, об'єкт-процес, хто, кого, куди, звідки, час, дата, А320, А321, В-747, умова, висновок, висота, швидкість, Д пол, вантажопідйомність, швидкість, велика, середня, мала, від, до, більше, менше, м, км, с, необхідно, можливо, дозволено, доцільно, всі, деякі, існує, обов'язково, наявне (НВ), відсутне (ВДС), невизначено (НЕВИЗН), суперечливо (ПРОТ), невідомо (НЕВІД), більше, менше, структура, прогноз, розпізнавання, обмеження, ресурси, оцінки, час, дата, км/год, А, а, Б, б, В, в, Г, г, ..., Я, я, A, a, B, b, C, c, D, d, ... 1, 2, 3, 4, 5, 6, 7, 8, 9, 0, ", . ; : $\}$.

Серед базових одиниць термінального словника можуть бути виділені елементи які $\epsilon$ об'єктами певних категорій предметної галузі.

Відображення (відносини) пов'язують між собою об'єкти зовнішнього світу, тому словоформам термінального словника може бути приписана семантична інформація відповідно до структури предметної галузі [9].

Опис об'єктів категорій предметної галузі

Пропонується така деталізація опису об'єктів категорій предметної галузі.

1. Класи (Кл $\left.{ }_{\mathrm{i}}\right)$ - використовують для позначення однорідних груп фактів, подій, явищ та інших елементів реального світу. (Наприклад, клас структури системи управління повітряним рухом регіону, структури системи повітряних суден для пасажирських авіаперевезень, засобів отримання радіолокаційної інформації тощо).

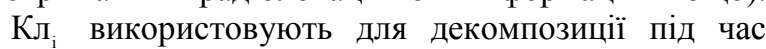
аналізу конкретної ситуації, $\epsilon$ переважно статичними і такими, що не потребують частого коригування.

2. Стани (Cs) -елементи, що фіксують певний якісний стан об'єкта предметної галузі. (Наприклад, вільна злітно-посадкова смуга, резервний канал, запасний аеродром).

3. Ознаки простору (Првl) - характеризують просторове положення, протяжність, а також геометричну структуру об'єкта. Як категорії простору можуть бути використані мовні одиниці “район”, “маршрут”, “ешелон”, “рубіж” тощо.

4. Ознаки часу (Чt) - характеризують плин подій у часі (рік, місяць, день, година, хвилина), та ïх узгодженість (взаємне існування) в часовому вимірі (одночасно, раніше, пізніше).

5. Дії (Дd ) - об’єкти категорій, які описують динаміки предметної галузі. Прикладами дій можуть бути поняття “виведення”, “наведення”, "розпізнавання" тощо.

6. Процеси (Прцр) - лінгвістичні одиниці, які характеризуються певною послідовністю дій (наприклад процеси підготовки, прийняття рішень, виконання комплексу операцій тощо).

До особливої групи об'єктів категорій належить група лінгвістичних елементів мови ознак, основними з них є:

характеристики (Харх ) - висота, швидкість, вантажопідйомність тощо.

ознаки міри характеристики (МХар). Серед них виділяють ознаки міри часу - МЧ (хвилина, година, тиждень, місяць, рік тощо) та ознаки міри простору - МПрв (кілометри, метри, фути тощо.).

ознаки якості ( Як ) - велика, мала, середня.

ознаки імені (Ім ) - будь-які слова, словосполучення, а також порядкові числівники (наприклад, рейс ВТ-401, термінал 3 тощо).

У природній мові користувачі використовують лексичні одиниці, які задають опис модальності процесів та явищ, а також враховують склад об'єктів у поняттях (квантифікацію). Щоб користувачі не зіштовхувалися 3 проблемою порядку опису модальностей та кванторів, а мова взаємодії наближалася до природної мови користувачів, доцільно використовувати природномовні описи модальностей і кванторів, а також враховувати їх під час обробки відповідно до обраної формальної системи. Для реалізації цього положення запропоновано виокремити такі ознаки:

ознаки модальності (Мод) - можуть, необхідно, можливо тощо.

ознаки квантифікації ( Кв ) - існує, все, кожний, деякий, якийсь.

Наступним етапом $\epsilon$ розроблення правил переписування, необхідних для формування (розпізнавання) мовних об'єктів.

Розроблення продукційних правил формальної граматики.

Аксіомою граматики є така “формула”: $\mathrm{A}=\{$ Формула $(\Phi)\}$.

IIII формують відповідно до таких продукцій:

П1. $\Phi \rightarrow<$ ТОб; СтТ $>$.

П2. ТОб $\rightarrow$ Роль: IO, КО3, ТО, CI.

де IO - унікальне ім'я, за яким можна розпізнати об'єкт або його теорію. КОЗ - код області знань, який визначає “можливий світ” об'єкта (теорії структур об'єктів, їх прогнозованих станів, обмежень тощо); ТО - тип конкретного об'єкту; СI - службова інформація про теорію обєкта (процедури, квантори, модальності, оператори, коментарі, оцінки присутності); роль - опис призначення об'єкта в іншому об'єкті.

Для компактного запису теорії об'єкта слід використовувати такі правила.

П3. ТОб $\rightarrow$ Роль.

П4. ТОб $\rightarrow \mathrm{IO}, \mathrm{KO} 3, \mathrm{TO}, \mathrm{CI}$.

П5. ТОб $\rightarrow$ IO, CI.

П6. ТОб $\rightarrow$ Роль: IO,CI.

Правила П3 - П6 враховують відсутність ряду синтаксичних елементів (IO, КО3, ТО) в описі теорії об'єкта.

П7. Роль $\rightarrow$ ім'я ролі (конст1, ІОП), де константа1 (конст1) характеризує причину зміни оцінки присутності та може набувати одного 3 наступних значень: 
П8. Конст $1 \rightarrow$ СТАТ| ВИВОД| ТЕОРІЯАрядок, де СТАТ описує структуру у статиці, ВИСНОВОК характеризує зміну оцінки присутності в результаті логічного висновку, ТЕОРІЯАрядок теорію, в результаті якої відбулася зміна оцінки присутності.

Зміна оцінки присутності (ЗОП) задається такими правилами переписування:

П9. ІОП $\rightarrow$ Конст2-Конст2.

П10.Конст2 $\rightarrow$ ПР|ВІДС|НЕВИЗН|ПРОТ|НЕВІД, де ПР - присутність, ВІДС - відсутність, НЕВИЗН - невизначено, ПРОТ - протиріччя, НЕВІД невідомо (повна апріорна невизначеність).

Іменем ролі можуть бути такі елементи:

П11. Ім'я ролі $\rightarrow$ ПідКлАрядок| ПідЦ $\Lambda$ рядок ПідЗад $\Lambda$ яядок| Оз $\Lambda$ яядок| Обм $\Lambda$ рядок| рядок| ВхД де ПідКл, ПідЦ, ПідЗад, Оз, Обм, ВхД, ВихД, Перед, Дія, Підл відповідно бути підкласом, підціллю, підзадачею, ознакою, обмеженням, вхідними та вихідними даними, ЦУ, яка передує, ЦУ в результаті виконання дії, підлеглою ЦУ; Семв - об'єкт виконує роль семантичного відмінника в іншому об'єкті. У разі потреби користувач може ввести свої позначення залежно від типу об'єкта та можливого світу який розглядають.

П12. Ім'я об’єкта $\rightarrow$ IO| ЗО| ІПОб| ВР| ХарЧ

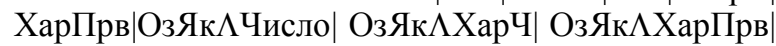
рядок,

де IO - ім'я ознаки, $3 \mathrm{O}$ - значення ознаки, ІПОб ім'я підоб'єкта, ВР - виконавець ролі.

П13. Пр $\rightarrow$ Ім $\mid$ Вл $\mid$ Атр $\mid$ Синт $\mid$ Кільк $\mid$ Доп,

де Ім - бути іменем, Вл - бути властивістю, Атр бути атрибутом, Синт - невільне сполучення, Кільк - бути в кількості, Доп - бути допоміжним.

П14. Ім $\rightarrow$ С $\Lambda$ рядок|рядок $\Lambda \mathrm{C}$

П15. Вл $\rightarrow$ П $\Lambda$ С

П16. Атр $\rightarrow \mathrm{C} \Lambda \mathrm{C}$

П17. Синт $\rightarrow \mathrm{C}($ Синт $) \Lambda \mathrm{C}($ Синт $)|\Gamma \Lambda \mathrm{O}| \mathrm{O} \Lambda \Gamma$

П18. Кільк $\rightarrow$ Ч $\Lambda$ С $\mid$ Чс $\Lambda \mathrm{C}$

П19. Доп $\rightarrow$ Г(Доп) $\Lambda$ С(Доп)

П20 Семв $\rightarrow$ С (Семв $) Г($ Семв $)$

П21. ХарЧ $\rightarrow$ МЧАчисло-число ММЧ характеристика часу.

П22. МЧ $\rightarrow$ сек $\mid$ хв $\mid$ год| доба| місяць $\mid$ рік,

де МЧ - міра часу.

П23. Число $\rightarrow$ цифра.

П24. Цифра $\rightarrow$ цифра-цифра.

П25. ХарПрв $\rightarrow$ число $\Lambda$ МЧ,

Де ХарПрв - характеристика простору.

П26. МПрв $\rightarrow$ м| км - міра простору.

П27. ОзЯк $\rightarrow$ більше| менше $\mid$ не більше| не менше.

П28. КОЗ $\rightarrow$ КОД: область.

П29. Область $\rightarrow$ структура| прогноз| обмеження| ресурси $\mid$ оцінки| область $\Lambda$ рядок| рядок| $\Lambda$.

П30. CI $\rightarrow$ CI, CI.

П31. Рядок $\rightarrow$ слово.

П32. Слово $\rightarrow$ слово $\Lambda$ слово.

П33. Слово $\rightarrow$ буква|цифра|*.

П34. Буква $\rightarrow \mathrm{A}|\mathrm{a}| \mathrm{B}|\mathrm{B}| . .|Я| я|\mathrm{~A}| \mathrm{a}|\mathrm{B}| \mathrm{b}|\mathrm{C}| \mathrm{c}|\mathrm{D}| \mathrm{d} .$.

П35. $* \rightarrow-|+| . \mid$ ?| !

П36. Цифра $\rightarrow 1|2| 3|4| 5|6| 7|8| 9 \mid 0$.

П37. ТО $\rightarrow$ об'єкт-клас| об'єкт-дія| об'єкт-стан| об'єкт-процес приклад| тип даних| ЦУ.
П37а.Тип даних $\rightarrow$ числовий| символьний| логічний.

П38. ТО $\rightarrow$ ТО $\Lambda$ рядок| рядок.

П39. СІ $\rightarrow$ Мод| Комент: рядок $\mid$ Кв $\mid$ ОцПр| Проц $\Lambda$ строка| $\Lambda \mid$ Тип вершини

П39а. Тип вершини $\rightarrow$ ДИЗ'ЮНКТ| КОН'ЮНКТ.

П40. Мод $\rightarrow$ необхідно| можливо| обов'язково| дозволено| заборонено| доказово| спростовно.

П41. Кв $\rightarrow$ існує| всі| деякі| завжди| інколи| всюди.

П42. ОцПр $\rightarrow$ ПР $\mid$ ВІДС $\mid$ НЕВИЗН $\mid$ ПРОТ.

Крім зазначених, необхідно також задати правила утворення структури теорії об'єкта.

П43. СтТ $\rightarrow$ ТОб.

П44. ТОб $\rightarrow$ (ТОб) $\mid$ [ТОб]|/ТОб/ $\mid\{$ ТОб $\} \mid$ Не ТОб.

П45. ТОб - ТОб:ТОб.

Заповнення певних елементів формул, таких як “ім'я ролі”, “ім'я об'єкта”, “назва теорії” тощо, покладається повністю на користувачів. Цей аспект передбачає володіння додатковими знаннями про семантику предметної галузі. Наприклад, якщо об’єкт виконує роль “бути ознакою часу" або “ознакою простору”, то як значення ознаки мають стояти словоформи, що характеризують час або простір. Це можливо врахувати за допомогою семантичних правил.

CП1. П11, S(ПрПрВ) $\rightarrow$ П12, S(ХарПрВ).

Запис СП1 означає, якщо у правилі П11 $€$ словоформа 3 семантичною ознакою ПрПрВ, то в ході побудови формули необхідно застосовувати правило П12 та використовувати ті одиниці словника, які мають семантичну ознаку ХарПрВ.

Аналогічно записують і решту правил.

СП2. П11, S(ПрЧ) $\rightarrow$ П12,S(ХарЧ).

СП3. П11, S(Кл1) $\rightarrow$ П12,S(Кл1).

$\mathrm{C} \Pi 4$. П11, S(Cs) $\rightarrow$ П12,S(Cs).

$\mathrm{C}$ 15. П11, S(Дd) $\rightarrow$ П12,S(Дd).

CП6. П11, S(Прцр) $\rightarrow$ П12,S(Прцр).

Щодо використання розробленої внутрішньої мови системи для опису теорії об'єкта предметної галузі можна навести такі приклади:

Приклад 1. 3 даними планової та радіолокаційної інформації в зоні відповідальності АС УПР передбачена ситуація спільного використання повітряного простору з можливим перетином у часі та просторі пасажирськими літаками В-747, А-320 та А-321. Повітряні судна виконують планові міжнародні авіарейси 3 пасажирських перевезень.

Структура знань наведена на рис. 1.

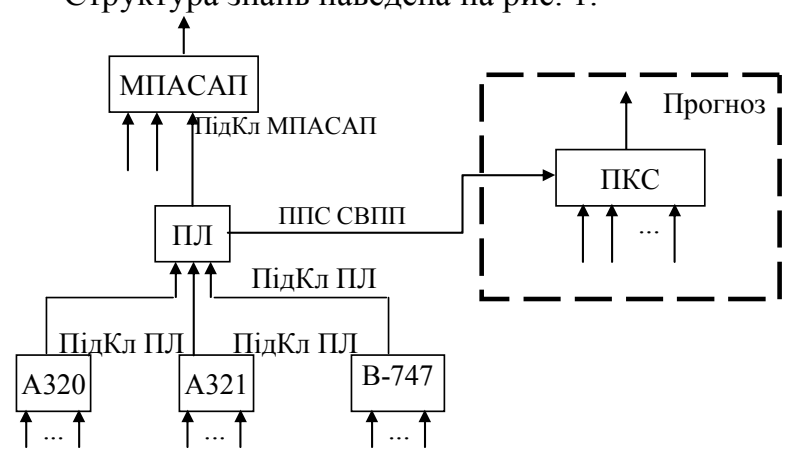

Рис.1. Приклад структури знань

Пасажирський літак (ПЛ) у цьому прикладі 
виконує дві ролі і входить до підкласу пасажирських літаків, що виконують міжнародні авіаперевезення, та входять до складу групи повітряних суден, що спільно використовують повітряний простір із можливим виникненням потенційної конфліктної ситуації (ПКС) внаслідок перетину маршрутів в просторово-часовій площині, тобто $є$ джерелом потенційної проблемної ситуації (ППС) спільного використання повітряного простору (СВПП) у зоні відповідальності АС УПР. При цьому із об'єкта ПЛ вихідні морфізми формуються через ті самі вхідні морфізми.

Формальною мовою ця структура може бути задана таким чином:

$<$ ПідКл МПАСАП(СТАТ,ОТС-ПР):ПЛ, об'єктклас МПАСАП, КОД: структура;

(ПідКл1 ПЛ(СТАТ,ПР-ПР):А-320, необхідно;

ПідКл2 ПЛ(СТАТ,ПР-ПР):А-321,

необхідно;

ПідКл3 ПЛ(СТАТ,ПР-ПР):В-747,

можливо >.

$<$ ППС СВПП(Теорія прогнозу, ОТС-ПР): ПЛ, об'єкт-клас МПСАП;

/ПідКл1 ПЛ(Теорія прогнозу, НЕВІД-ПР):

А-320, можливо;

ПідКл2 ПЛ(Теорія прогнозу, ОТС-ПР):

А-320, можливо;

ПідКлЗ ПЛ(Теорія прогнозу, НЕВИЗН-

ПР): В-747, можливо/>.

цей запис відповідає повній структурі категорійної моделі знань.

Приклад 2. Теорія тільки об'єкта ПЛ 3 використанням внутрішньої мови буде мати такий вигляд:

<ПідКл МПАСАП(СТАТ, ПР-ПР), КОД: структура;

(ПідКл1 ПЛ(СТАТ, ПР-ПР), необхідно;

ПідКл2 ПЛ(СТАТ, ПР-ПР), необхідно;

ПідКл3 ПЛ(1, ПР-ПР), можливо)>,

$<$ ППС СВПП(Теорія прогнозу, ОТС-ПР);

/ПідКл1 ПЛ(Теорія прогнозу, НВІД-ПР),

можливо;

ПідКл2 ПЛ(Теорія прогнозу, ОТС-ПР),

можливо;

ПідКлЗ ПЛ(Теорія прогнозу, НЕВИЗН-ПР), можливо/>.

Приклад 3. Формула, що відображає фрагмент структури МПАСАП з прикладу 1, матиме такий вигляд:

<ПідКл МПАСАП: СА, КОД :структура;

(ПідКл1 ПЛ:А-320;

ПідКл2 ПЛ:А-321;

ПідКл3 ПЛ:В-747)>.

Для підтвердження коректності та працездатності розробленої формальної граматики слід провести розбір довільної формули.

Граматичний розбір дає змогу не тільки підтвердити, що цей мовний об'єкт належить до внутрішньої мови системи, а $\epsilon$ можливість побудувати структуру вхідного ланцюга, для подальшої роботи з “деревом виводу”, а саме відшукуванні підоб'єктів, об'єднання їх між собою, створення топологічного простору теорії об'єкта тощо.

Можливості розробленої формальної граматики розглянуто за допомогою граматичного розбору першої формули 3 прикладу 2 (рис.2).

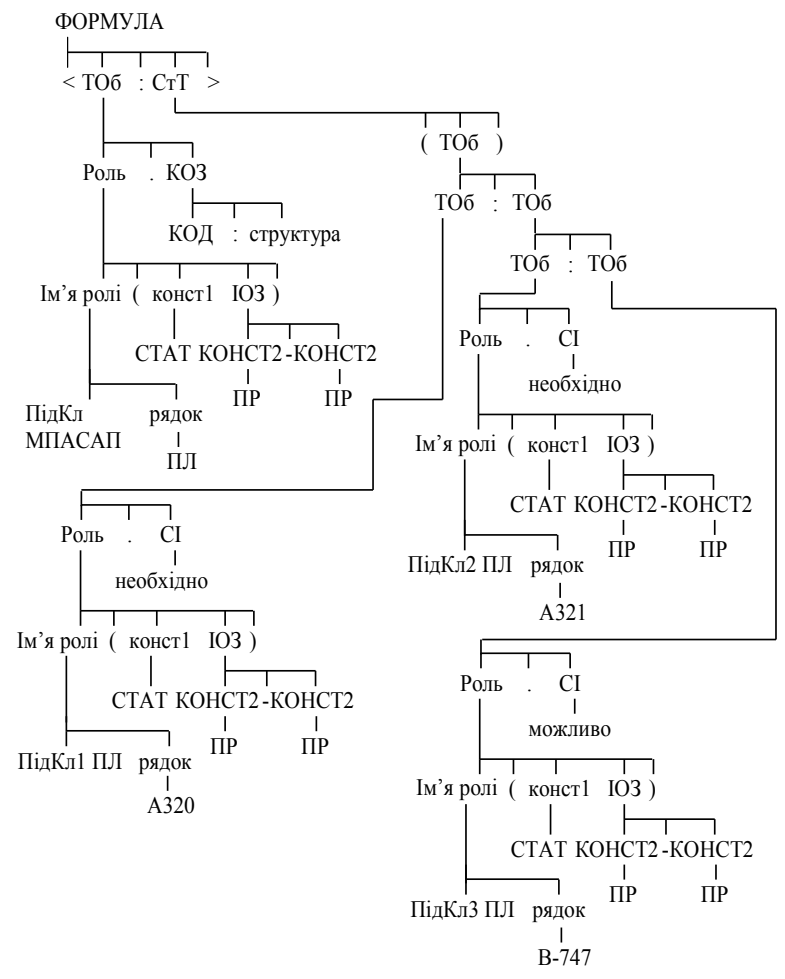

Рис. 2. Результат граматичного розбору формули

Запропонована внутрішня мова системи дає змогу формально описувати теорії різноманітних об’єктів предметної галузі. 3 точки зору практичних застосувань користувачам цього явно не достатньо, оскільки процес взаємодії з СППР спрямований на досягнення конкретних цілей, що і потрібно враховувати.

Для забезпечення маніпулювання знаннями доцільно використовувати прагматичні функції, а для вказання місцеположення інформації у формулі - індикаторний спосіб пошуку шляху.

Це положення проілюстроване для пошуку інформації, розміщеної в описі першої формули прикладу 1. Цей шлях матиме такий вигляд:

$<$ ПідКл МПАСАП(СТАТ, ПР-ПР): ПЛ;

(ПідКл1 ПЛ(СТАТ, ПР-ПР):?;

ПідКл2 ПЛ(СТАТ, ПР-ПР):?;

ПідКлЗ ПЛ(СТАТ, ПР-ПР):?)>.

Функції, необхідні для маніпулювання знаннями та їх семантика наведені в табл.1. 
Таблиця 1

Функції маніпулювання знаннями i ïx семантика

\begin{tabular}{|c|c|}
\hline Функція & Семантика функції \\
\hline $3 \mathrm{~A} \Pi<\Phi>$ & Запис формули в базу знань \\
\hline $\mathrm{KOP}<\mathrm{IO}>$ & $\begin{array}{l}\text { Корегування формули } 3 \\
\text { відповідним ім'ям }\end{array}$ \\
\hline ВИВ $<$ Роль $>$ & $\begin{array}{l}\text { Запуск алгоритму логічного } \\
\text { висновку }\end{array}$ \\
\hline ТЕОР $<$ Роль $>$ & $\begin{array}{l}\text { Побудова ієрархічної } \\
\text { структури теорії предметної } \\
\text { галузі }\end{array}$ \\
\hline ВидОб < Роль $\mid \mathrm{IO}>$ & $\begin{array}{l}\text { Видача повної структури } \\
\text { формули з відповідними } \\
\text { iм'ям або роллю (морфізмом) }\end{array}$ \\
\hline $\begin{array}{l}\text { ВидПОб } \\
<\text { Роль|ІО }>\end{array}$ & $\begin{array}{l}\text { Видача морфізмів } \\
\text { (підоб'єктів), що входять до } \\
\text { складу об’єкта, через } \\
\text { вказання відповідного імені } \\
\text { об’єкта або вихідного } \\
\text { морфізму }\end{array}$ \\
\hline ВидС $<\mathrm{IO}>$ & $\begin{array}{l}\text { Видача службової інформації } \\
\text { про теорію об'єкта }\end{array}$ \\
\hline ВидІО <П> & $\begin{array}{l}\text { Видача всіх імен морфізмів } \\
\text { (об’єктів) за ознакою П, де } \\
П \rightarrow \mathrm{KO}|\mathrm{TO}| \mathrm{CI} \mid \mathrm{IO} \\
\end{array}$ \\
\hline ОцПр < Роль $>$ & $\begin{array}{l}\text { Оцінка присутності } \\
\text { відповідної ролі }\end{array}$ \\
\hline $\begin{array}{l}\text { ВидКОМ } \\
<\text { Роль|ІО }>\end{array}$ & $\begin{array}{l}\text { Видача коментарів за } \\
\text { формулою об’єкта }\end{array}$ \\
\hline ПОБУД < IO > & $\begin{array}{l}\text { Побудова повного простору } \\
\text { формули об’єкта (видання } \\
\text { всіх вихідних і результуючих } \\
\text { морфізмів (ролі) певного } \\
\text { об'єкта }\end{array}$ \\
\hline ЗНИЩ < Роль|IО > & Знищення формули об’єкта \\
\hline ВизнТО <ІО $>$ & Визначення типу об’єкта \\
\hline Ріш< IO > & $\begin{array}{l}\text { Запуск на рішення задачі } 3 \\
\text { відповідним ім'ям }\end{array}$ \\
\hline
\end{tabular}

Таким чином, отримано опис всіх елементів формальної граматики G(L), внаслідок чого можна стверджувати про досягнення поставленої мети.

\section{Висновки і перспективи подальших}

\section{1. Фітература} інформаційних ознак для формування моделі повітряної обстановки / Ю. І. Полонський, І.О.Борозенець, С. Г. Шило, М. І. Литвиненко // Зб. наук. пр. Харківського національного університету Повітряних Сил. - 2016. № 2. - С. 115-117. 2. Рейуорд-Смит, В. Дж. Теория формальных языков. Вводный курс. - М.: Радио и свіязь, 1988. -128 с. 3. Грищук Т. В. Розпізнавання природної мови на граматичних марковських мережах / Т. В. Грищук // Наукові праці Донецького національного технічного університету. Серія: “Обчислювальна техніка та автоматика". - Донецьк: ДонНТУ, 2005. С. 181-187. 4. Ярушек В. Е. Теоретические основы автоматизации процессов выработки решений в системах управления / В. Е. Ярушек, В. П. Прохоров, Б. Н. Судаков, А. В. Мишин - Харьков: ХВУ, 1993. - 446 с. 5. Пентус А. Е. Теория формальных языков: учеб. пособие / А. Е. Пентус, М. Р. Пентус. - М.: Изд-во ЦПИ при механико-математическом ф-те МГУ, 2004. - 80 с. 6. Волкова И. А. Формальные грамматики и языки.

\section{досліджень}

Розроблено модель внутрішньої мови системи підтримки прийняття рішення операторами АC УПР, яка враховує специфіку функціональних задач 3 управління повітряним рухом шляхом застосування лінгвістичних, синтаксичних та семантичних особливостей побудови мовних об'єктів предметної галузі.

Аналіз отриманих продукційних правил показує, що розроблена внутрішня мова системи описана КС-граматикою, тому, що ліві частини продукцій належать до базового словника нетермінальних символів $\alpha \in \mathrm{V}_{\mathrm{N}}$, а праві - до доповнення об'єднання словника нетермінальних $\mathrm{i}$ термінальних символів $\beta \in\left(\mathrm{V}_{\mathrm{T}} \cup \mathrm{V}_{\mathrm{N}}\right)^{+}$.

Введення у граматику семантичних ознак дає змогу стверджувати про отримання модифікованої КС-граматики, яка розширює відомі КС-граматики (за Хомським). Крім того, запропонована граматика дає змогу управляти висновком, збільшуючи ступінь детермінованості розпізнавання (породження) ланцюгів мови.

За правилами перепису можна не лише синтезувати нові вирази, а й розпізнавати вже створені. Використання правил як інструменту синтезу дає змогу автоматизувати процес генерації меню для користувачів та забезпечити поповнення словника.

Враховуючи, що як елементи словника використано лексику професійної мови користувачів, всім нетермінальним символам надано певне семантичне навантаження, що полегшить користування словником спеціалістами, які неповною мірою володіють специфікою побудови бази знань, але $є$ фахівцями у предметній галузі.

За допомогою отриманої моделі можна надалі реалізувати на формальному рівні процес взаємодії внутрішньої мови системи з обмеженою природною мовою взаємодії користувачів.

Элементы теории трансляции: учеб. пособие для студентов II курса / И. А. Волкова, А. А. Вылиток, Т. В. Руденко - изд. 3-е, перераб. и доп.). - М.: Изд. отдел ф-та ВМиК МГУ им. М. В. Ломоносова (лицензия ИД N 05899 от 24.09.2001), 2009. - 115 с. 7. Мельников Б. Ф. Подклассы класса контекстно - свободных языков. Б.Ф.Мельников. - М.: МГУ, 1995. - 174 с. 8. Бондаренко М. Ф. Теория интеллекта / М. Ф. Бондаренко, Ю. П. Шабанов-Кушнаренко. Харьков: Компания СМИТ, 2006. - 576 с. 9. Дзюба Е. В. Лингвокогнитивная категоризация в русском языковом сознании: монография / Е. В. Дзюба; Урал. гос. пед. унт. - Екатеринбург, 2015. - 286 с. 10. Саломаа А. Жемчужины теории формальных языков. Ж. Саломаа. М.: Мир, 1986. - 159 с. 11. Шабанов-Кушнаренко Ю. П. Компараторная идентификация лингвистических объектов: Монография / Ю. П. Шабанов-Кушнаренко, Н. В. Шаронова. - К.: ИСДО, 1993. - 116 с. 12. Бондаренко М. Ф. Концепції уніфікації інформаційноінтелектуальних технологій в системах мовлення / 
М. Ф. Бондаренко, З. Д. Коноплянко, Г. Г. Четвериков // Бионика интеллекта : науч.-техн. журн. - Харьков: ХНУРЭ, 2011. - Вып. 3 (77). - С. 150-156. 13. Шаронова Н. В. Использование метода компараторной идентификации для разбиения семантического пространства предметной области знаниеориентированных систем / Н. В. Шаронова, Н. Ф. Хайрова // Вестник Херсон. гос. техн. ун-та. - Херсон, 2007. - № 4 (27). - С. 39-42. 14. Шаронова Н. В. Метод персонификации интеллектуального корпоративного ресурса компании / Н. В. Шаронова, В. А. Тарловский, Н. Ф. Хайрова // Зб. наук. пр. "Вісник Національного технічного університету "Харківський політехнічний інститут". - Тематичний випуск: Інформатика i моделювання. - Харьков: НТУ “ХПІ", 2009. - № 43. С. 191-197. 15. Оробинская Е. А. Языковая компетенция информационных систем / Е. А. Оробинская, О. И. Король, Н.В.Шаронова // Зб. наук. пр. "Вісник Національного технічного університету "Харківський політехнічний інститут". Серія: Інформатика та моделювання. - Харків: НТУ "ХПІ". - 2012. - № 62 (968). - С. 148-154. 16. Шаронова Н.В. Использование логических сетей для формирования баз знаний логического типа Н. В. Шаронова, В. А. Тарловский, Н. Ф. Хайрова // Вісник Херсон. Нац. техн.. ун-ту. - Херсон: ХНТУ. 2011. - № 41. - С. 184-188. 17. Павленко М. А. Разработка метода многоэтапной формализации знаний о процессе распознавания оперативно-тактических ситуаций / М. А. Павленко, П. Г. Бердник, С. В. Кукобко, Ю. В. Данюк // Системи обробки інформації. - Харків: ХУПС, 2012. - Вип. 5(103). - С. 60-64. 18 Павленко М. А. Разработка процедуры формализации модальных знаний с использованием теории нечетких множеств для экспертных систем реального времени / М. А. Павленко, А. И. Тимочко, А. Н. Бесчасный, В. П. Докучаев // Зб. наук. пр. ХУПС. Харків: ХУПС, 2012. - Вип. 3 (32). - С. 122-125. 19. Павленко М. А. Метод формализации знаний о процессе распознавания ситуаций нарушения правил движения воздушными судами / М. А. Павленко // Системи управління, навігації і зв'язку. - К.: ДП “ЦНДІ HiУ”, 2012. - Вип. 2 (22). - С. 86-92. 20. Математические основы эргономических исследований: монография / П. Г. Бердник, Г. А. Кучук, и др. - Кропивницкий: КЛА НАУ, 2016. - 248 с.

\title{
МОДЕЛЬ ВНУТРЕННЕГО ЯЗЫКА СИСТЕМЫ ПОДДЕРЖКИ ПРИНЯТИЯ РЕШЕНИЙ АВТОМАТИЗИРОВАННОЙ СИСТЕМЫ УПРАВЛЕНИЯ ВОЗДУШНЫМ ДВИЖЕНИЕМ
}

\author{
${ }^{1}$ Михаил Иванович Литвиненко (канд. техн. наук, доцент.) \\ ${ }^{2}$ Владимир Сергеевич Мажнаров \\ ${ }^{3}$ Сергей Игоревич Антоненко
}

\begin{abstract}
${ }^{1}$ Харьковский национальный университет Воздушных Сил имени Ивана Кожседуба, Харьков, Украина ${ }^{2}$ Кировоградская летная академия национального авиационного университета, Кропивницкий, Украина ${ }^{3}$ Национальный университет обороны Украины имени Ивана Черняховского, Киев, Украина
\end{abstract}

В статье предложена модель ограниченного внутреннего языка системы поддержки принятия решений, которая является необходимой составляющей для реализации процесса взаимодействия между интеллектуальной системой и операторами автоматизированной системы управления воздушным движением. Разработанная модель является необходимым и обязательным средством формализации процессов управления воздушным движением в рамках функиионирования системь поддержки принятия решений с иелью повышения уровня автоматизации процессов формирования текстовых сообщений в звеньях “диспетчер - диспетчер” и “диспетчер - воздушное судно”. Согласно методологии построения формальной грамматики предложена структура словарей терминальных и нетерминальных признаков, с достаточной детализачией описаны объекты категорий предметной области, разработаны продукционные правила формальной грамматики. Корректность полученного аппарата и возможность дальнейшего практического использования внутреннего языка системь подтверждены приведенными примерами представления знаний на предложенном языке и грамматическим разбором конструкиий формул объектов.

Ключевые слова: информационная модель, формальная грамматика, терминальнье $и$ нетерминальные символь, семантические признаки, продукиионные правила.

\section{INTERNAL LANGUAGE ENGINEERING SYSTEM FOR SUPPORTING SOLUTIONS OF AUTOMATED AIR TRAFFIC CONTROL SYSTEM \\ ${ }^{1}$ Michael I. Litvinenko (PhD, Senior Research Fellow), \\ ${ }^{2}$ Volodymyr S. Mazharov \\ ${ }^{3}$ Serhii I. Antonenko}

\author{
${ }^{1}$ Ivan Kozhedub Kharkiv National Air Force University for Educational Work, Kharkiv, Ukraine \\ ${ }^{3}$ Kirovohrad Flight Academy of National Aviation University, Kropivnitskyi, Ukraine \\ ${ }^{3}$ National Defense University of Ukraine named after Ivan Cherniakhovsky, Kyiv, Ukraine
}

The paper proposes a model of the decision support system limited internal language, which is a necessary component for realizing the process of interaction between the intellectual system and the operators of the automated air traffic control system. The developed model is a necessary and indispensable tool for formalizing air traffic control processes within the functioning of the decision support system in order to increase the level of automation of the generating text messages processes in the "dispatche - dispatcher" and "dispatcher - air vessel." The structure of terminal and nonterminal characters dictionaries is proposed according to the methodology of constructing formal grammar; the objects of categories of the subject area are described with sufficient detail; the production rules of formal grammar are developed. The correctness of the received 
apparatus and the possibility of the system internal language further practical use are confirmed by the knowledge of given examples of representation in the proposed language and the grammatical analysis of the objects formulas structures.

Keywords: informational model, formal grammar, terminal and nonterminal symbols, semantic signs, production rules.

\section{References}

1. Polonsky Y. Formalized description of the selection process for forming informational signs model air situation [Formalizovanyy opys protsesu vidboru informatsiynykh oznak dlya formuvannya modeli povitryanoyi obstanovky] / Y. Polonsky, I. Borozenets, S. Shiloh, M. Litvinenko // Coll. Science. works. Kharkov National University of the Air Force. - 2016. - № 2. - P. 115-117. 2. Reyuord-Smith B. The theory of formal languages. Introductory course [Teoryya formal nykh yazykov. Vvodnyy kurs] - M :: Radio and communication, 1988. -128 p. 3. Grischuk T. Recognition of natural language grammar Markov networks [Rozpiznavannya pryrodnoyi movy na hramatychnykh markovs kykh merezhakh] TV Grischuk // Scientific Papers of Donetsk National Technical University. Series: "Computer science and engineering." - Donetsk: DonNTU, 2005. - P. 181-187. 4. Yarushek V. Theoretical Foundations of automated decision-making processes in the management [Teoretycheskye osnovy avtomatyzatsyy protsessov vyrabotky reshenyy $\mathrm{v}$ systemakh upravlenyya] / V. Yarushek, V. Prokhorov, B. Sudakov, A. Mishin - Kharkiv: HVU, 1993. - 446 p. 5. Pentus A. Theory of formal languages studies. Manual [Teoryya formal nykh yazykov: ucheb. posobye] / A. Pentus, M. Pentus. - M $\therefore$ Izd TSPY with mechanics-mathematical faculty that Moscow State University, 2004. - 80 p. 6. Volkova I. Formal grammars and languages. Elements of the theory of translation: Proc. allowance for students II course [Formal nye hrammatyky y yazyky. Élementy teoryy translyatsyy: ucheb. posobye dlya studentov II kursa] - M .: Publishing. Division of Computer Sciences and Faculty of Moscow State University named after Lomonosov (license ID from 24.09.2001 N 05899), 2009. - 115 p. 7. Melnikov B Subclasses of context - free languages [Podklassy klassa kontekstno - svobodnykh yazykov] / B. Melnykov. - M .: Moscow State University, 1995. - 174 p. 8. Bondarenko M. Theory of intelligence [Teoryya yntellekta] / M. Bondarenko, P. ShabanovKushnarenko. - Kharkov: SMIT Company, 2006. - 576 p.

9. Dzyuba E. Lingvokognitive categorization in Russian language consciousness: monograph [Lynhvokohnytyvnaya katehoryzatsyya $\mathrm{v}$ russkom yazykovom soznanyy: monohrafyya] / E. Dzyuba; Ural. state. ped. Univ. Ekaterinburg, 2015. - 286 p. 10. Salomaa A. Pearls of formal language theory [Zhemchuzhyny teoryy formal nykh yazykov]. J. Salomaa. - M .: Mir, 1986. - 159 p. 11. Shabanov Y. Comparator identification of linguistic objects: Monograph [Komparatornaya ydentyfykatsyya lynhvystycheskykh ob'ektov: Monohrafyya]

Y.Kushnarenko Shabanov, N. Sharonov. - K .: YSDO, 1993. - 116 p. 12. Bondarenko M. Concept unification of intelligent information technologies in broadcasting [Kontseptsiyi unifikatsiyi informatsiyno-intelektual nykh tekhnolohiy v systemakh movlennya] / M. Bondarenko, Z. Konoplyanko, G. Chetverikov // Bionics Intelligence: scientific and engineering. Zh. - Kharkov: KNURE, 2011. -
Vol. 3 (77). - P. 150-156. 13. Sharonova N. The use of comparator for identifying the partition of the semantic spare domain knowledge-based systems [Yspol zovanye metoda komparatornoy ydentyfykatsyy dlya razbyenyya semantycheskoho prostranstva predmetnoy oblasty znanyeoryentyrovannykh system] / N. Sharonova, N. Hayrova // Bulletin of Kherson. state. tehn. Univ. - White Church, 2007. № 4 (27). - P. 39-42. 14. Sharonova N. Intellectual corporate resource of the company personalization method [Metod personyfykatsyy yntellektual noho korporatyvnoho resursa kompanyy] / E. Orobynskaya, A. King, N. Sharonova // Coll. Science. pr. "Proceedings of the National Technical University" Kharkiv Polytechnic Institute ". - Series: Information and Modeling. - Kharkov: NTU "KPI". - 2012. № 62 (968). - P. 148-154. 15. Orobynskaya E. Language Competence Information Systems [Yazykovaya kompetentsyya ynformatsyonnykh system] // Coll. Science. pr. "Proceedings of the National Technical University" Kharkiv Polytechnic Institute ". - Series: Information and Modeling. - Kharkov: NTU "KPI". - 2012. - № 62 (968). P. 148-154. 16. Sharonova N. Using logical networks to form a knowledge base of logical type [Yspol zovanye lohycheskykh setey dlya formyrovanyya baz znanyy lohycheskoho typa] / N. Sharonova, V. Tarlovskiy N. Hayrova // Bulletin of Kherson. Nat. .. Technical Univ. Kherson: KHNTU. - 2011. - № 41. - P. 184-188. 17. Pavlenko M. A multi-stage method of knowledge formalization development for the process of tactical situations recognition [Razrabotka metoda mnohoétapnoy formalyzatsyy znanyy $o$ protsesse raspoznavanyya operatyvno-taktycheskykh sytuatsyy] / M. Pavlenko, P. Berdnikov, S. Kukobko, V. Danyuk // Information processing systems. - Kharkov: KhUAF, 2012. - Vol. 5 (103). - P. 60-64. 18. Pavlenko M. Procedures formalization of modal knowledge developing by using fuzzy sets theory to real-time expert systems [Razrabotka protsedury formalyzatsyy modal nykh znanyy $\mathrm{s}$ yspol zovanyem teoryy nechetkykh mnozhestv dlya ékspertnykh system real noho vremeny] / M. Pavlenko, A. Tymochko, A. Beschasnыy, V. Dokuchaev // Coll. Science. works KhUAF. - Kharkov: KhUAF, 2012. - Vol. 3 (32). - P. 122-125. 19. Pavlenko M. Formalization of knowledge about the process of situations traffic aircraft violations recognition method [Metod formalyzatsyy znanyy o protsesse raspoznavanyya sytuatsyy narushenyya pravyl dvyzhenyya vozdushnymy sudamy] / M. Pavlenko // Command and control systems, navigation and communication. - K .: CRI NiU, 2012. - Vol. 2 (22). - P. 86-92. 20. Berdnikov P. Mathematical foundations of ergonomic research: Monograph [Matematycheskye osnovy érhonomycheskykh yssledovanyy: monohrafyya] / P. Berdnik, G. Kuchuk - Kropyvnytskyi:. DV of NAU, 2016. - $248 \mathrm{p}$. 